\title{
Gender Differences in Regional Fatty Acid Metabolism Before and After Meal Ingestion
}

Michael D. Jensen

Endocrine Research Unit, Mayo Clinic, Rochester, Minnesota 55905

\begin{abstract}
These studies were conducted to determine whether men and women differ with regards to their overnight postabsorptive (basal) and postprandial fatty acid kinetics. Systemic oleate turnover $\left(\left[9,10^{3} \mathrm{H}\right]\right.$ oleate $)$ was measured before and after the consumption of a mixed meal. Leg and splanchnic free fatty acid (FFA) uptake and release were measured, allowing the calculation of upper-body subcutaneous FFA release. Results: basal oleate flux was virtually identical in men and women $(3.0 \pm 3$ versus $2.9 \pm 0.4 \mu \mathrm{mol} \cdot \mathrm{kg}$ $\left.\mathrm{FFM}^{-1} \cdot \min ^{-1}\right)$, however, oleate Ra suppressed more in women than in men following meal ingestion $(0.5 \pm 0.1$ versus $\left.0.8 \pm 0.1 \mu \mathrm{mol} \cdot \mathrm{kg} \mathrm{FFM}^{-1} \cdot \mathrm{min}^{-1}, P<0.05\right)$. The fractional contribution of basal, regional FFA release to total FFA flux was not significantly different between men and women. In contrast, oleate release by upper-body subcutaneous adipose tissue was significantly greater $(30 \pm 5$ vs $8 \pm 3 \mu \mathrm{mol} / \mathrm{min}$, respectively, $P<0.01$ ) in men than in women during the meal nadir of FFA flux, whereas splanchnic oleate release was a greater percentage $(39 \pm 7 \%$ vs $20 \pm 3 \%$, respectively, $P<0.05)$ of nadir oleate $R a$ in women than in men. Thus, normal weight men and women differ significantly in the postprandial regulation of adipose tissue lipolysis in that men's upper-body subcutaneous adipose tissue is more resistant to the antilipolytic effects of meal ingestion. Differential regulation of regional adipose tissue lipolysis could contribute to the gender based differences in body fat distribution. (J. Clin. Invest. 1995. 96:2297-2303.) Key words: adipose tissue $\bullet$ lipolysis $\bullet$ body composition • insulin • triglycerides
\end{abstract}

\section{Introduction}

Increased free fatty acid (FFA) availability may contribute to some of the metabolic abnormalities associated with obesity and non-insulin-dependent diabetes mellitus. Increased FFA result in resistance to insulin mediated glucose uptake in skeletal muscle $(1,2)$, resistance to insulin suppression of endogenous glucose production ( 3 ), reduced hepatic insulin clearance (4), and hypertriglyceridemia (5). Upper-body obese women have increased basal (6) and postprandial (7) FFA availability compared with lower-body obese or non-obese women, and are at increased risk for the metabolic complications of obesity (8).

Address correspondence to Michael D. Jensen, M.D., Endocrine Research Unit, 5-164 W. Joseph, Mayo Clinic, Rochester, MN 55905. Phone: 507-255-6449; FAX: 507-255-4828.

Received for publication 27 February 1995 and accepted in revised form 18 July 1995.

J. Clin. Invest.

(C) The American Society for Clinical Investigation, Inc. 0021-9738/95/11/2297/07\$2.00

Volume 96, November 1995, 2297-2303
We have previously reported that upper-body subcutaneous fat is more lipolytically active than lower body fat in women, and that upper body fat is the source of the excess FFA release in upper-body obese women (9). The factors which determine where body fat will be preferentially stored are unknown, however.

Upper-body obesity and lower-body obesity are referred to as android and gynoid obesity for good reason. Women have a greater portion of body fat on the hip and thigh area than men $(10)$, who have more visceral fat than women $(11,12)$. These gender-related differences in body fat distribution could be related to regional variations in FFA release rates. For example, if lower body adipose tissue FFA release rates in men were equal to upper body adipose tissue FFA release, this could account for the reduced lower body fat mass in men compared with women. No information is currently available regarding regional lipolytic rates in men.

Another factor which could significantly influence body fat distribution, and therefore the health effects of excess weight gain, is preferential storage of meal triglyceride fatty acids in certain adipose tissue beds. Recent studies have documented that upper body and lower body adipose tissue take up meal triglyceride to different degrees, as assessed by isotopic labeling of meal triglycerides followed by adipose tissue biopsy (13). Net storage of fat in adipose tissue over time, however, must represent the combination of both the uptake and release of fatty acids. Only the former assessment can be made with the meal tracer/adipose tissue biopsy technique of Mårin et al. (13, 14). A more complete understanding of the factors influencing body fat distribution requires the measurements of regional FFA release rates, preferentially, under both postabsorptive and postprandial conditions. The relative contribution of these two processes may differ in men and women, and if so, this may provide insight as to the mechanisms by which "healthy" (lower body) versus "unhealthy" (upper body) fat is deposited.

These studies were therefore conducted to test the hypothesis that under overnight postabsoptive conditions, upper body and lower body FFA release relative to fat mass would be similar in men, but that upper body fat would be more lipolytically active than lower body fat in women. The hypothesis that men and women would differ in regards to the regional suppression of FFA release following meal absorption was also examined. The results indicate substantial gender-related differences are present, which could help explain regional differences in body fat distribution between men and women.

\section{Methods}

Subjects. Written informed consent was obtained from 16 non-obese men and premenopausal women. All volunteers were in good health taking no medications, and had maintained a stable weight for more than two months before the studies. A summary of the subjects' characteristics is provided in Table $I$.

Materials and Assays. [Carboxyl- ${ }^{14} \mathrm{C}$ ] triolein and $\left[9,10^{3} \mathrm{H}\right]$ oleate were obtained from NEN Research Products, Willington, DE. Indocya- 
nine green (Cardio-Green, Becton Dickinson, and Company, Cockeysville, MD) was used in these studies.

Plasma oleate and FFA concentrations and oleate SA were determined by a modification (15) of a published HPLC technique (16) using $\left[{ }^{2} \mathrm{H}_{31}\right]$ palmitate as an internal standard. Plasma insulin (17) was measured by radioimmunoassay, and plasma glucose concentrations were measured using a YSI glucose analyzer (Yellow Springs, $\mathrm{OH}$ ). Femoral artery, femoral vein, and hepatic vein plasma triglyceride concentrations were measured in triplicate twice using a microfluorometric method (18). To measure the specific activity of triglyceride oleate (in meal and plasma), triglycerides were separated from nontriglyceride fatty acid containing lipids using a modification of the method of Christie (19). In brief, lipid extracts of the sample were injected onto a 5 micron Spherisorb Silica column (length, $250 \mathrm{~mm}$, ID $4.6 \mathrm{~mm}$ ) from Alltech Associates Inc. (Deerfield, IL) in a running buffer of isooctane:tetrahydrofuran (99.6:0.4) at $2 \mathrm{ml} / \mathrm{min}$. With this system, the triglyceride peak elutes at $\sim 5 \mathrm{~min}$ and is sufficiently separate from the cholesterol ester peak that complete collections of the triglyceride fraction contain no cholesterol esters. Non-esterified fatty acids are eluted by changing the buffer to methanol:isopropanol (80:20) at $13 \mathrm{~min}$. The triglyceride fraction is hydrolyzed using methanolic sodium hydroxide, the fatty acids derivatized and injected on the HPLC (16). The non-esterified fatty acid fraction is collected separately and, for plasma, can be derivatized and used for measurement of FFA concentration and SA $(15,16)$.

Body fat and fat free mass, as well as leg fat, were measured using dual energy x-ray absorptiometry (Lunar Radiation, Madison, WI) (20). Plasma indocyanine green concentrations were measured using a spectrophotometer. Analysis of plasma samples for the indocyanine green concentrations was performed on the day of the study using precautions as previously described (9).

Protocol. Each subject consumed all meals as provided by the Mayo Clinic General Clinical Research Center (GCRC) for two weeks prior to the study. The diet provided $40 \%$ of energy intake as fat, $40 \%$ as carbohydrate, and $20 \%$ as protein. Each volunteer was weighed to within $0.1 \mathrm{~kg}$ every morning and energy intake adjusted, if needed, to achieve weight maintenance over the two-week interval. During a final seven to ten days, weight stability was achieved for each subject; therefore, the energy intake during this time was used to determine daily energy requirements. Each subject was then admitted to the GCRC the evening before the study, and an 18-gauge infusion catheter was placed in a forearm vein and infused with $0.45 \% \mathrm{NaCl}$ at $20 \mathrm{ml} / \mathrm{h}$. Blood was sampled before starting the indocyanine green infusions to be used for construction of the indocyanine green calibration curve and as background for the plasma oleate specific activity. Prior to meal consumption, each subject underwent two 10-minute measurements of oxygen consumption and $\mathrm{CO}_{2}$ excretion using a DeltaTrac Metabolic Cart (Sensor Medics, Yorba Linda, CA) to predict resting energy expenditure.

The morning of the study, volunteers were transferred to the Vascular Radiology Laboratory where a 5-Fr Terumo sheath was introduced into the right femoral artery using standard percutaneous technique. A $20 \mathrm{~cm}$ long, 4-Fr straight catheter with six distally placed side holes (special order Cook) was placed through the sheath with the catheter tip in the common iliac artery. This catheter was used for arterial blood sampling, and the sheath was used to infuse indocyanine green. The right femoral vein was then punctured in a similar manner and a 6-Fr Terumo sheath introduced. The distal tip of the sheath was placed in the external iliac vein a few centimeters above the inguinal ligament. A 5-Fr Simmons II catheter with four distal side holes (special order Cook) was placed through the sheath and the catheter tip placed in the right hepatic vein. Catheter position was confirmed with the injection of about $5 \mathrm{ml}$ iodinated contrast material. A solution of $0.45 \%$ sodium chloride was infused through the sheaths and the catheters to maintain patency. The volunteers were then transferred back to the GCRC for completion of the study.

The experimental meal was prepared as follows: approximately 50 $\mu \mathrm{Ci}$ of $\left[{ }^{14} \mathrm{C}\right]$ triolein dissolved in $1 \mathrm{ml}$ of ethanol was added to each individual's liquid meal (Ensure Plus, Ross Laboratories) and sonicated for $10 \mathrm{~min}$ with a Heat Systems Inc (Farmingdale, NY) Ultrasonic Processor $\mathrm{XL}$ to assure incorporation of the tracer into the meal triglyc- erides. Samples of the meal were saved for assay of triglyceride oleate specific activity. The experimental meal was measured to within $2 \mathrm{ml}$ for each individual and calculated to provide one-third of daily energy needs. The meal contained $53 \%$ of energy as carbohydrate, $32 \%$ as fat, and $15 \%$ as protein.

After being transferred back to the GCRC, the volunteers were allowed to rest in bed for $90 \mathrm{~min}$. An infusion of $\left[9,10-{ }^{3} \mathrm{H}\right]$ oleate $(0.3$ $\mu \mathrm{Ci} / \mathrm{min}$ ) was begun through the forearm vein infusion catheter 30 minutes prior to the first blood sample. Arterial, femoral venous, and hepatic venous blood samples were taken at 15 -min intervals over 30 min before the meal consumption. The liquid meal was consumed over a 10-20 min interval and blood samples were obtained at 30-min intervals for the $6 \mathrm{~h}$ after meal consumption. After completion of this study, all catheters were removed and local hemostasis was obtained. The subjects remained in the hospital under observation until the following morning.

Special precautions were taken to assure that in vitro hydrolysis of plasma triglycerides did not occur. Blood samples were immediately placed on ice, spun in a refrigerated centrifuge within $15 \mathrm{~min}$, aliquoted and frozen immediately thereafter. In addition, diethyl-p-nitro-phenylphosphate $(0.04 \%)$, an inhibitor of lipoprotein lipase mediated in vitro triglyceride hydrolysis, was added to the blood sample tubes for the first three volunteers. There was no differences between these studies and the remaining studies as regards the appearance of meal ${ }^{14} \mathrm{C}$-oleate in the plasma FFA oleate fraction.

Calculations. Systemic total oleate Ra was calculated from the $\left[{ }^{3} \mathrm{H}\right]-$ oleate tracer using non-steady state equations (21). During meal absorption, some of the FFA appearing in the circulation originate from meal triglycerides (7), therefore the appearance of the meal $\left[{ }^{14} \mathrm{C}\right]$ oleate in plasma can be measured using the ratio of plasma to meal oleate SA and systemic oleate $\mathrm{Ra}(7)$. Meal oleate $\mathrm{Ra}$ was calculated as:

Meal oleate $\mathrm{Ra}=\frac{\text { plasma }\left[{ }^{14} \mathrm{C}\right] \text { oleate } \mathrm{SA} \times \text { oleate } \mathrm{Ra}}{\text { meal }\left[{ }^{14} \mathrm{C}\right] \text { oleate } \mathrm{SA}}$

Endogenous oleate $\mathrm{Ra}$ is the difference between total oleate $\mathrm{Ra}$ and meal oleate $\mathrm{Ra}$.

Plasma oleate concentrations and specific activity were constant over the baseline sampling interval, as was splanchnic and leg blood flow; therefore, steady state plasma oleate specific activity and concentration were used together with measures of leg and hepatic plasma flow to measure regional (splanchnic and leg) oleate uptake and release $(9,22$, 23). After meal ingestion a new steady state nadir (at least 30-60 $\mathrm{min}$ ) of oleate concentration (change $5 \pm 1 \mu \mathrm{mol} /$ liter) and SA (change $10 \pm 1 \%$ ) in arterial plasma was documented in each individual. Together with stable regional blood flow, these conditions permitted the calculation of steady-state meal nadir leg and splanchnic oleate uptake and release. Considering the brief circulating half-life of FFA (3-4 min), the nadir values of regional oleate release were obtained over an extended time interval ( $7-20$ half-lives ). The meal nadir occurred as early as 90-150 min after the meal (three subjects) and as late as $210-270$ min postprandially (one subject).

Systemic oleate flux values were combined with leg and splanchnic oleate release data obtained under basal and meal nadir conditions to estimate nonsplanchnic, upper-body oleate release as follows:

nonsplanchnic upper body oleate release $=$ total oleate flux

$-[($ leg oleate release $\times 2)+($ splanchnic oleate release $)]$

Oleate release per $\mathrm{kg}$ fat free mass, per $\mathrm{kg}$ leg fat, and per $\mathrm{kg}$ upperbody fat were calculated as previously described (9).

The net basal release of triglycerides from the splanchnic bed was assessed by multiplying the hepatic venous-femoral artery plasma concentration difference by splanchnic plasma flow. Likewise, leg triglyceride uptake was calculated by multiplying the femoral artery-femoral venous difference by leg plasma flow.

Statistics. All results are expressed as mean \pm SEM. Comparisons between men and women were made using a nonpaired $t$ test, and comparison between basal and nadir systemic and regional oleate release 
Table I. Subject Characteristics

\begin{tabular}{lcc}
\hline & Men $(n=8)$ & Women $(n=8)$ \\
\hline Age (yrs) & $27 \pm 2$ & $27 \pm 3$ \\
Weight $(\mathrm{kg})$ & $77.9 \pm 3.3$ & $62.5 \pm 2.1$ \\
Height $(\mathrm{cm})$ & $182 \pm 1$ & $166 \pm 3$ \\
Percent body fat & $16.1 \pm 1.1$ & $29.4 \pm 1.1$ \\
Fat free mass (kg) & $64.5 \pm 2.2$ & $44.7 \pm 1.7$ \\
Leg fat (kg) & $2.24 \pm 0.28$ & $3.73 \pm 0.11$ \\
& & \\
\hline
\end{tabular}

With the exception of age, all variables are significantly $(P<0.01)$ different in men and women.

rates within groups were made using a two-tailed paired Student's $t$ test.

\section{Results}

Subject characteristics. Male participants in this study were significantly taller and heavier than the women and had less body fat, less leg fat, and greater fat free mass (Table I). Lower body fat represented $34 \pm 2$ and $41 \pm 2 \%$ of body fat in men and women, respectively ( $P=0.01$, men vs women). Resting energy expenditure was $1655 \pm 69 \mathrm{kcal} / \mathrm{d}$ for men and $1272 \pm 49$ $\mathrm{kcal} / \mathrm{d}$ for women $(P<0.01$ versus men $)$. The test meal, providing one-third of daily energy needs for weight maintenance, was $906 \pm 54 \mathrm{kcal}$ for men ( $54 \%$ of REE) and $708 \pm 36$ kcal for women ( $56 \%$ of REE).

The hepatic vein catheter in one female and one male participant became dislodged after the baseline sampling; therefore, postprandial splanchnic FFA data are missing for one man and one woman.

Glucose and insulin. Mean plasma glucose concentrations were virtually identical in men and women for the $6 \mathrm{~h}$ after the meal (Fig. 1, bottom). Plasma insulin concentrations were also similar (Fig. 1, top), with peak, postmeal plasma insulin con-

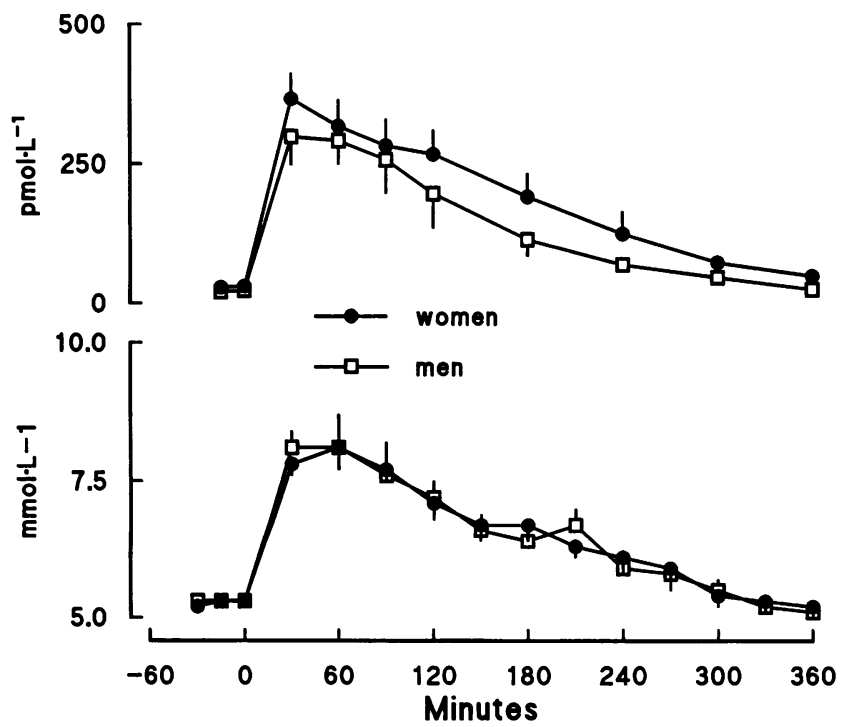

Figure 1. Plasma insulin (top) and glucose (bottom) concentrations before and after meal consumption in women (closed circles) and men (open squares).
Table II. Contribution of the Major Individual FFA to Total Plasma FFA

\begin{tabular}{lrrrrrrr}
\hline & \multicolumn{3}{c}{ Basal } & & \multicolumn{3}{c}{ Meal } \\
\cline { 2 - 4 } \cline { 7 - 8 } & $\begin{array}{c}\text { Femoral } \\
\text { artery }\end{array}$ & $\begin{array}{c}\text { Femoral } \\
\text { vein }\end{array}$ & $\begin{array}{c}\text { Hepatic } \\
\text { vein }\end{array}$ & $\begin{array}{c}\text { Femoral } \\
\text { artery }\end{array}$ & $\begin{array}{c}\text { Femoral } \\
\text { vein }\end{array}$ & $\begin{array}{c}\text { Hepatic } \\
\text { vein }\end{array}$ \\
\hline Palmitate (\%) & $21 \pm 1$ & $19 \pm 1$ & $20 \pm 1$ & $19 \pm 1$ & $18 \pm 1$ & $20 \pm 1$ \\
Oleate (\%) & $37 \pm 1$ & $38 \pm 1$ & $39 \pm 1$ & $25 \pm 1^{*}$ & $24 \pm 1$ & $26 \pm 1$ \\
Linoleate (\%) & $28 \pm 1$ & $29 \pm 1$ & $26 \pm 1^{\ddagger}$ & $40 \pm 1^{*}$ & $42 \pm 2$ & $37 \pm 2^{\ddagger}$ \\
Stearate (\%) & $6 \pm 1$ & $6 \pm 1$ & $7 \pm 1$ & & $6 \pm 1$ & $6 \pm 1$ & $7 \pm 1$
\end{tabular}

${ }^{*} P<0.05 \mathrm{cf}$ basal values (arterial only); ${ }^{\ddagger} P<0.05 \mathrm{cf}$ arterial values.

centrations of $346 \pm 50 \mathrm{pmol} /$ liter in women and $299 \pm 53 \mathrm{pmol} /$ liter in men $(P=\mathrm{NS})$. Likewise, the area under the insulin curve for the 6 hours after the meal was also similar in women and men ( $65 \pm 9$ versus $50 \pm 6 \mathrm{nmol} /$ liter, respectively, $P=\mathrm{NS})$.

Individual/total plasma FFA concentrations. Analysis of the meal triglyceride fatty acid samples revealed that linoleate was the predominant fatty acid ( $>2.5$ times the molar equivalent of oleate). Special precautions were therefore taken to measure the nine individual plasma free fatty acid (arachidonic, linolenic, palmitoleic, myristic, linoleic, palmitic, oleic, elaidic, and stearic) concentrations in plasma samples obtained before and after the meal. The percent contribution of four major FFA to total arterial plasma FFA concentrations before and after the meal are provided in Table II. Oleate contributed a lesser $(P$ $<0.05$ ) proportion of plasma FFA concentrations in postmeal samples, whereas linoleate contributed a greater $(P<0.05)$ percent. There were no significant differences in the contribution of oleate to total FFA concentrations between femoral artery, femoral vein, and hepatic vein blood under postabsorptive or postprandial conditions. Linoleate was a lesser $(P<0.05)$ percent of total FFA in hepatic venous than arterial plasma under both basal and post-meal circumstances, consistent with previous reports (23).

Systemic oleate kinetics. Oleate concentrations and $\left[{ }^{3} \mathrm{H}\right]$ oleate SA in femoral artery, femoral vein, and hepatic vein plasma are depicted in Fig. 2. Basal oleate flux was $188 \pm 17$ and $128 \pm 15 \mu \mathrm{mol} / \mathrm{min}$ in men and in women, which was virtually identical when related to metabolically active tissue $(3.0 \pm 0.3$ vs $2.9 \pm 0.4 \mu \mathrm{mol} \cdot \mathrm{kg} \mathrm{FFM}^{-1} \cdot \min ^{-1}$, respectively). Total oleate $\mathrm{Ra}$ decreased rapidly after meal consumption (Fig. 3, top) reaching new steady-state nadir values of $49 \pm 6$ and $24 \pm 3$ $\mu \mathrm{mol} / \mathrm{min}$ in men and women respectively, between 90 and 240 min after meal consumption. Oleate Ra relative to FFM and arterial oleate concentrations in men and women are provided in Fig. 4. The nadir of total oleate Ra was significantly less in women than men $\left(0.5 \pm 0.1\right.$ vs $0.8 \pm 0.1 \mu \mathrm{mol} \cdot \mathrm{kg} \mathrm{FFM}^{-1}$. $\left.\min ^{-1}, P<0.05\right)$. Meal $\left[{ }^{14} \mathrm{C}\right]$ oleate began to appear in the plasma FFA/oleate pool 30-60 min after meal ingestion and continued to rise until the end of the experiment, when total oleate $\mathrm{Ra}$ was increasing (Fig. 3). The nadir of endogenous (nonmeal) oleate Ra was also less in women $(11 \pm 2 \mu \mathrm{mol} / \mathrm{min}$ ) than men $(28 \pm 5 \mu \mathrm{mol} / \mathrm{min})(0.3 \pm 0.1$ versus $0.5 \pm 0.1 \mu \mathrm{mol} \cdot \mathrm{kg}$ $\mathrm{FFM}^{-1} \cdot \min ^{-1}$, respectively, $\left.0.05<P<0.1\right)$.

Regional oleate release. Because basal oleate flux relative to fat free mass was the same in men and women, regional oleate release was examined both in absolute $\left(\mu \mathrm{mol} \cdot \mathrm{min}^{-1}\right)$ and relative (percent of total) terms in order to assess genderrelated differences. Under overnight postabsorptive conditions, 


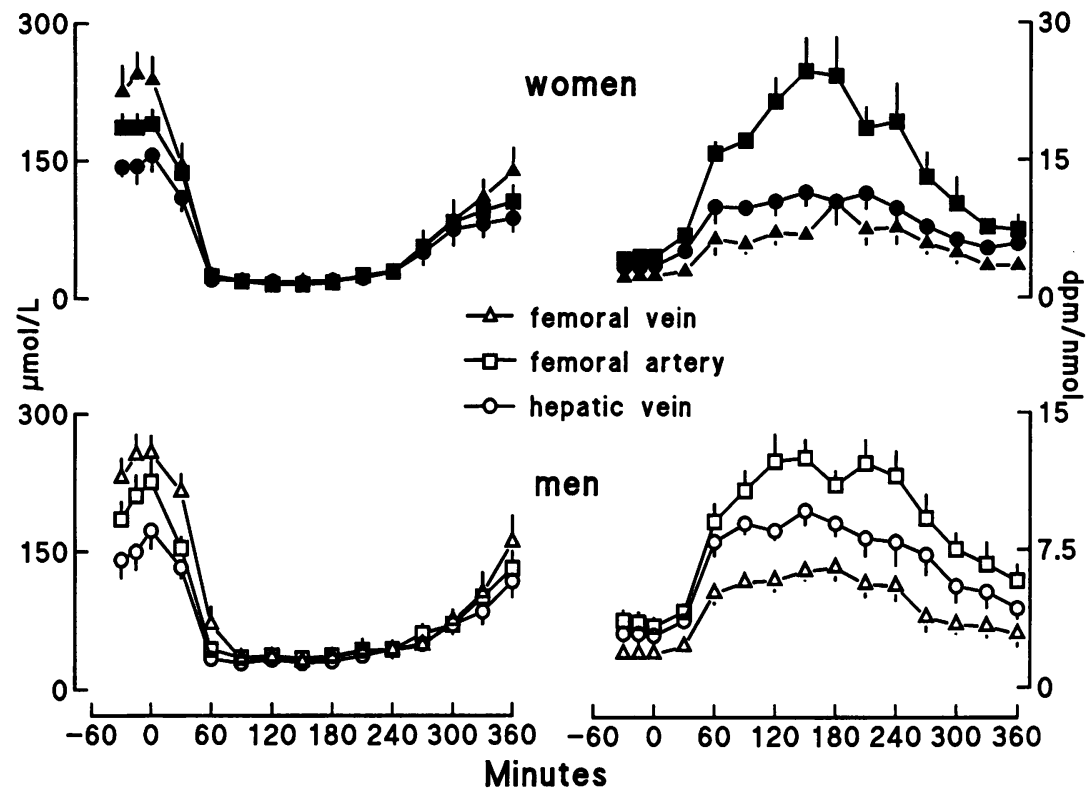

Figure 2. Plasma oleate concentrations (left) and $\left[{ }^{3} \mathrm{H}\right]$ specific activity (right) in femoral venous, femoral arterial, and hepatic venous blood in men and women before and following meal ingestion. the contribution of a single leg to systemic oleate release in men and women was $14 \pm 2$ and $19 \pm 2 \%$, respectively $(0.05<P$ $<0.1$, men vs women). The fraction of oleate Ra entering the systemic circulation from the splanchnic bed, and the proportion of systemic oleate flux attributable to nonsplanchnic, upperbody adipose tissue was not significantly different between women and men (Table III).

To compare regional adipose tissue oleate release relative to fat mass, leg and upper-body oleate release was normalized to leg and upper-body fat for each individual. For all participants, oleate release per $\mathrm{kg}$ upper-body fat was greater $(P$ $<0.05)$ than oleate release per $\mathrm{kg}$ leg fat $(12.4 \pm 1.9$ vs $9.2 \pm 1.2$ $\mu \mathrm{mol} \cdot \mathrm{kg} \mathrm{fat}^{-1} \cdot \mathrm{min}^{-1}$, respectively $)$. In men, oleate release per $\mathrm{kg}$ upper-body fat was greater than oleate release per $\mathrm{kg}$ leg fat $\left(17.2 \pm 2.7 \mathrm{vs} 11.9 \pm 1.7 \mu \mathrm{mol} \cdot \mathrm{kg} \mathrm{fat}{ }^{-1} \cdot \mathrm{min}^{-1}\right.$, respectively, $P$ $=0.05$ ), whereas the difference was not as great in women

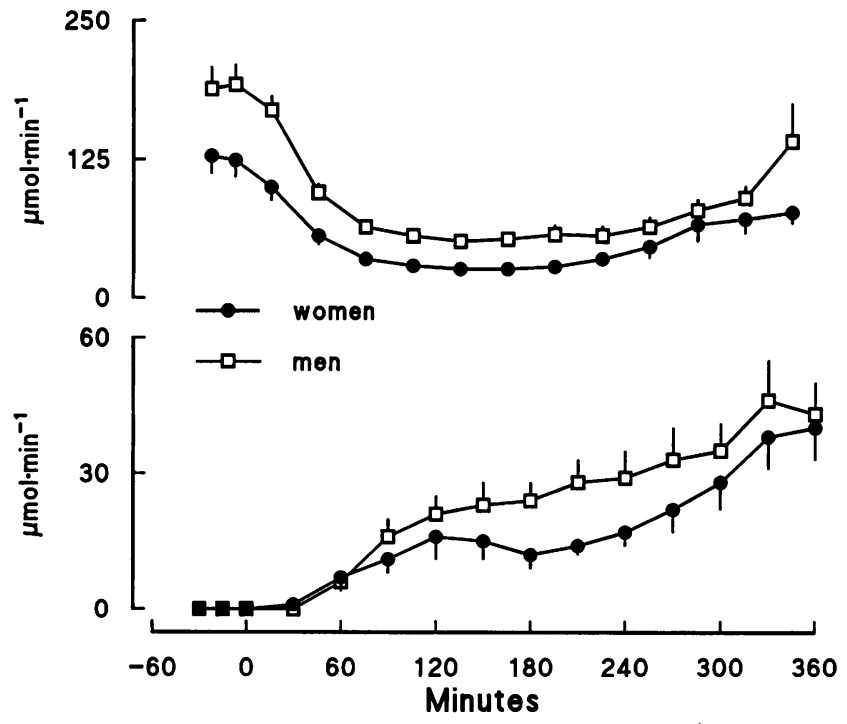

Figure 3. Total oleate rate of appearance ( $\mathrm{Ra}$ ) (top) and meal oleate rate of appearance (bottom) in women and men before and following the ingestion of the meal.
(7.6 \pm 1.4 vs $6.4 \pm 1.1 \mu \mathrm{mol} \cdot \mathrm{kg}$ fat $\cdot \mathrm{min}^{-1}$, respectively, $P$ $=\mathrm{NS}$ ). As anticipated, oleate release per $\mathrm{kg}$ leg fat and per $\mathrm{kg}$ upper-body fat was greater in men than in women (both $P$ $<0.05$ ).

For each individual, steady-state systemic and regional oleate release were calculated for the nadir of meal suppressed lipolysis and compared in the same fashion that basal values were compared. At the nadir of meal suppression of FFA flux, leg oleate release in men accounted for a lesser $(P<0.01)$ percentage of total oleate flux than it did under basal conditions, and a lesser $(0.05<P<0.1)$ proportion than was observed in women (Table III, Fig. 5). The fractional contribution of nadir leg oleate release to nadir systemic oleate $\mathrm{Ra}$ in women was also somewhat less $(0.05<P<0.1)$ than under basal conditions. In women, but not in men, splanchnic oleate release accounted for a greater $(P<0.01)$ percent of nadir systemic

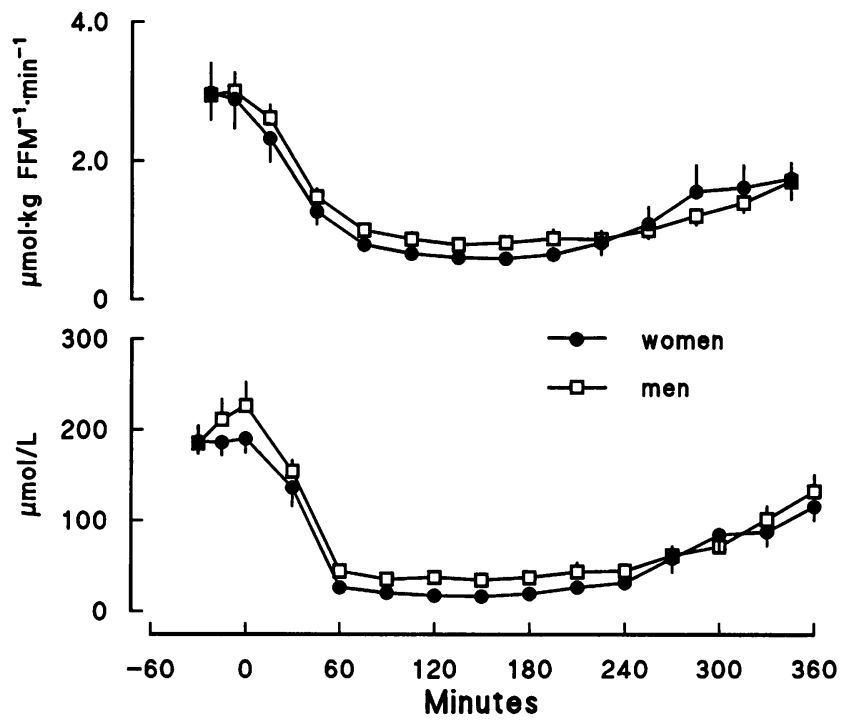

Figure 4. Oleate rate of appearance relative to fat free mass (top) and plasma oleate concentrations in women and men before and following meal ingestion. 


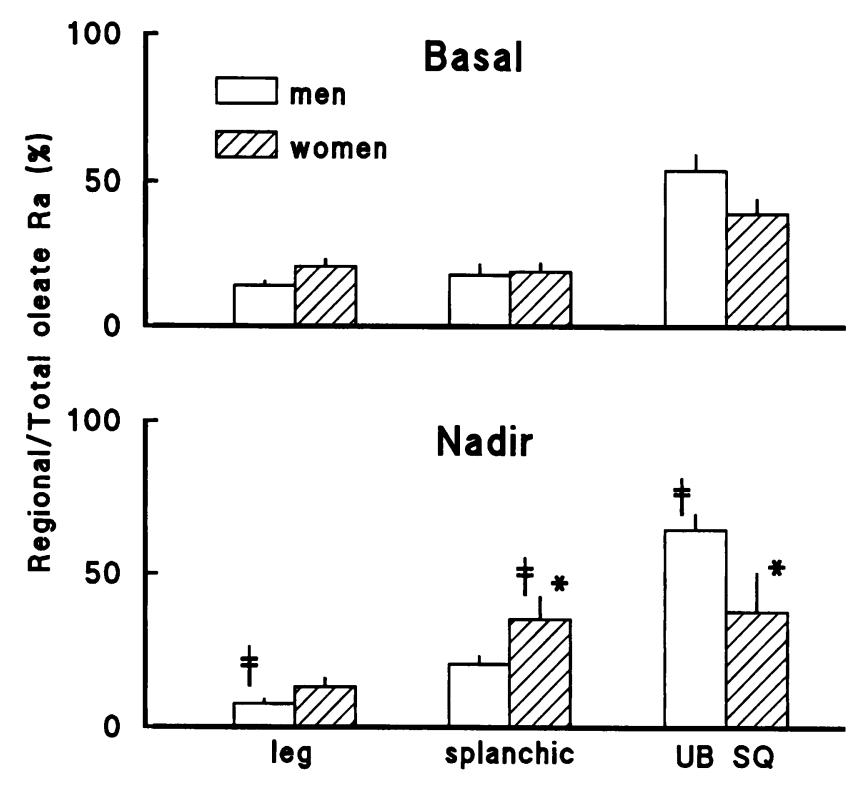

\begin{tabular}{lccccc}
\hline & \multicolumn{2}{c}{ Baseline } & & \multicolumn{2}{c}{ Nadir } \\
\cline { 2 - 3 } \cline { 5 - 6 } \cline { 5 - 6 } & Men & Women & & Men & Women \\
\hline $\begin{array}{l}\text { Leg release } \\
\mu \text { mol/min }\end{array}$ & $25 \pm 3$ & $24 \pm 4$ & & $4 \pm 1$ & $3 \pm 1$ \\
$\quad$ Percent of total & $14 \pm 2$ & $19 \pm 2$ & & $8 \pm 2^{\ddagger}$ & $14 \pm 3$ \\
$\begin{array}{l}\text { Splanchnic release } \\
\mu \text { mol/min }\end{array}$ & $34.9 \pm 9$ & $23 \pm 3$ & & $12 \pm 3$ & $8 \pm 1$ \\
$\quad$ Percent of total & $17 \pm 4$ & $19 \pm 3$ & & $20 \pm 3^{*}$ & $39 \pm 7^{\ddagger}$ \\
$\begin{array}{l}\text { Nonsplanchnic upper-body } \\
\text { release }\end{array}$ & & & & \\
$\quad \mu$ mol/min & $105 \pm 12$ & $57 \pm 10$ & & $30 \pm 5$ & $8 \pm 3$ \\
$\quad$ Percent of total & $55.5 \pm 5$ & $44 \pm 4$ & & $65 \pm 5^{\dagger}$ & $32 \pm 12^{*}$ \\
Leg uptake & & & & \\
$\quad \mu$ mol/min & $15 \pm 2$ & $14 \pm 3$ & & $5 \pm 1$ & $3 \pm 1$ \\
$\quad$ Percent of total & $8 \pm 1$ & $12 \pm 2$ & & $9 \pm 2$ & $11 \pm 2$ \\
Splanchnic uptake & & & & \\
$\quad \mu$ mol/min & $76 \pm 14$ & $53 \pm 7$ & & $9 \pm 2$ & $6 \pm 1$ \\
$\quad$ Percent of total & $39 \pm 5$ & $44 \pm 5$ & & $17 \pm 3^{\dagger}$ & $29 \pm 6^{\ddagger}$ \\
\hline
\end{tabular}

${ }^{*} P<0.05$ men vs women. ${ }^{\ddagger} P<0.05$ baseline vs nadir.

Figure 5. The percent contribution of leg, splanchnic, and upper-body subcutaneous adipose tissue beds to systemic oleate rate of appearance under basal (top) and meal nadir conditions in men and women. ${ }^{*} P$ $<0.05$ cf men, ${ }^{\ddagger} P<0.01$ cf basal.

oleate $\mathrm{Ra}$ than it did under basal conditions. In addition, splanchnic oleate release accounted for a greater $(P<0.05)$ share of systemic oleate $\mathrm{Ra}$ in women than in men during the meal nadir of FFA flux. In contrast, nonsplanchnic, upper-body oleate release provided a significantly greater percentage of nadir total oleate $\mathrm{Ra}$ in men than women. In men, but not in women, nonsplanchnic, upper-body oleate release explained a greater percentage $(P<0.01)$ of nadir systemic oleate Ra than it did basal oleate $\mathrm{Ra}$.

Regional oleate uptake. The proportion of oleate flux taken up by leg tissues was not significantly different in women and men and did not change from basal to meal nadir conditions (Table III). The splanchnic uptake of systemic oleate flux was also similar in women and men under basal conditions, but the fraction of systemic oleate flux removed in the splanchnic bed decreased $(P<0.05)$ in both women and men during the meal nadir of oleate flux.

Triglyceride metabolism. Basal plasma triglyceride concentrations were $737 \pm 114 \mu \mathrm{mol} / \mathrm{L}$ in men and $510 \pm 48 \mu \mathrm{mol} /$ liter in women $(P=\mathrm{NS})$. Plasma triglyceride concentrations increased after the meal to a maximum of $1,180 \pm 159$ and $693 \pm 80 \mu \mathrm{mol} /$ liter, respectively, in men and women $(P$ $<0.005$, men versus women). The average net release of triglycerides from the splanchnic bed under basal conditions was $77 \pm 26$ and $81 \pm 16 \mu \mathrm{mol} / \mathrm{min}$ in women and men, respectively $(P=\mathrm{NS})$. The average basal leg triglyceride uptake was $10.8 \pm 3.1$ and $6.7 \pm 0.8 \mu \mathrm{mol} / \mathrm{min}$ in women and men $(P=\mathrm{NS})$. After meal consumption, leg triglyceride uptake increased in a similar fashion in men and women averaging $24.4 \pm 8.6$ and $20.5 \pm 4.3 \mu \mathrm{mol} / \mathrm{min}$ during the last $1 \mathrm{~h}$ of the study in men and women ( $P=\mathrm{NS}$ men vs women $)$. No significant differences in the $\left[{ }^{3} \mathrm{H}\right]$ or $\left[{ }^{14} \mathrm{C}\right]$ triglyceride oleate SA were observed between arterial, hepatic venous, or femoral venous blood, although there was a tendency for the hepatic venous $\left[{ }^{3} \mathrm{H}\right]$ triglyceride oleate SA to be greater than arterial values (data not shown).

\section{Discussion}

These are the first studies to examine whether men and women differ with regards to regional postabsorptive and postprandial

fatty acid kinetics in vivo. Systemic, splanchnic, and leg FFA oleate release and uptake were measured before and after the consumption of a physiologic mixed meal in lean, healthy volunteers. Systemic FFA flux relative to fat free mass was nearly identical in men and women under postabsorptive conditions, however, in response to a mixed meal, systemic FFA flux in women was significantly more suppressed. Under basal conditions, the fractional contributions of regional adipose tissue oleate release to systemic oleate flux were comparable in men and women, although there was a tendency for leg fat oleate release to be greater in women. Upper-body adipose tissue was more lipolytically active than lower-body fat in men, similar to women in this study, and consistent with findings in women from a previous study (9). After meal consumption, FFA release from leg, splanchnic, and upper-body subcutaneous adipose tissue decreased in both men and women. Significant gender-related differences were found. Upper-body subcutaneous FFA release was less suppressible in men, whereas splanchnic FFA release was relatively less well suppressed in women. Thus, normal weight, healthy men and women differ in both their systemic and regional adipose tissue responses to meal ingestion.

Special precautions must be taken when studies of mealrelated fatty acid metabolism are undertaken to test for differences between men and women. At healthy, nonobese weights, women have more body fat, less fat-free mass, and therefore, lower resting and daily energy expenditures than men. Thus, providing men and women with equal sized meals might create different responses because of the unequal relative metabolic challenge posed by the meal. To avoid this confounding variable, and to eliminate the interindividual differences in relative macronutrient intake, men and women in the present study were fed a controlled, weight maintaining diet for 2 wk before the regional FFA kinetic study. The experimental meal was selected to provide the same relative metabolic challenge for each volunteer and to mimic a physiologic meal (one-third of daily energy expenditure). This approach appears to have been successful 
in as much as plasma glucose and insulin responses were similar in men and women. Therefore, although the experimental meal size, including the amount of triglyceride, carbohydrate, and protein, differed from individual to individual, and differed between men and women, the quantity relative to tissue needs was the same. It, therefore, seems unlikely that the differences in postprandial lipolysis between men and women were related to the variances in meal size between the two groups.

Although meal size did not create the observed differences in FFA metabolism between men and women, the possibility that differences in body fat could explain the results should be considered. Women participating in the present study had almost double the percent body fat of male volunteers. An increased percent body fat is characteristically associated with insulin resistance, both as regards glucose metabolism and suppression of FFA flux (24). In contrast, normal weight women in this study had greater suppression of FFA flux than agematched men, despite their greater percent body fat. This strongly suggests increased insulin sensitivity of adipose tissue lipolysis in women, the opposite of what should have been observed if differences in body composition between men and women accounted for the differences in FFA flux. It therefore seems reasonable to conclude that gender, not body composition differences, best explain the findings of this study.

It has been reported that insulin stimulated muscle glucose uptake is greater in women than men (25). If the glucosefatty acid cycle is operative after meal ingestion, the greater suppression of FFA availability in women could help explain this gender difference in glucose metabolism. Plasma FFA concentrations have been reported to be less in women than men two hours after an oral glucose tolerance test in some (26), but not all (27) studies. Higher postprandial plasma FFA predict greater plasma triglyceride concentrations (26). This is the first study to document that the reduced plasma FFA concentrations in women are due to differences in rate of appearance, rather than due to differences in clearance.

Regional lipolysis. Because the male fat distribution is not predominately lower body, it was anticipated that upper-body and lower-body adipose tissue FFA release rates in men might be similar. Instead, upper-body adipose tissue FFA release was found to be greater than lower-body adipose tissue FFA release in both men and women. These and previous in vivo findings (9) contrast with the observation that basal lipolysis in isolated gluteal $(28)$ and femoral $(29,30)$ adipocytes is greater than abdominal adipocyte lipolysis in both genders. The hormonal and catecholamine milieu of the postabsorptive state may combine to increase FFA release from upper-body adipocytes and decrease it from lower-body adipose tissue in vivo. Catecholamine regulated lipolysis in vitro is different in abdominal subcutaneous and gluteal adipocytes from both men and women (28), although the distinctions are less apparent in men than women. The contrasts between the basal lipolytic function of upperbody and lower-body fat in vivo are at least as great in men as in women. The greater upper-body adipose tissue FFA release in vivo is more striking considering that FFA release from visceral adipose tissue is not fully reflected in systemic FFA $\mathrm{Ra}$. The hepatic clearance of a portion of FFA released from visceral fat (31) implies that total upper body lipolysis is greater than that measured by tracer techniques.

The major gender difference in postprandial suppression of FFA release was the relative resistance of upper-body subcutaneous adipose tissue in men Table III. Indeed, the oleate Ra attributed to upper-body subcutaneous adipose tissue accounted for virtually the entire difference between men and women in the postprandial suppression of FFA Ra. Although splanchnic oleate release at the postprandial nadir was relatively less well suppressed in women than in men, the absolute release rates were similar (Table III). It should be noted that relative differences or changes in splanchnic FFA release could be secondary to alterations in hepatic uptake of newly released portal FFA or variations in the intra-abdominal adipose tissue response to postprandial antilipolytic conditions. If the relative suppression of visceral lipolysis is not as great in women, net postprandial fatty acid storage in visceral fat might be reduced; visceral adipose tissue mass is typically less in women than men $(10-12)$.

Note that FFA release from all regions decreased markedly following meal ingestion in both genders. This effect was almost certainly due to postprandial insulinemia. The impressive decrease in leg adipose tissue lipolysis after the meal clarifies some of the previous, conflicting data from in vitro studies of adipocytes. Some investigators report no decrease in lipolysis from femoral adipocytes in response to insulin $(29,30)$, whereas other have reported detectable antilipolytic effects of insulin on gluteal fat cells $(32-34)$. Although it is possible that site difference (gluteal versus femoral) account for the contradictory in vitro findings, it is also possible that the conditions of some in vitro studies do not reproduce the in vivo environment sufficiently to allow normal responses to occur.

Regional triglyceride metabolism. The contribution of postprandial regional fatty acid balance in determining body fat distribution is unknown. Coppack et al. (35) demonstrated a net positive carbon balance in abdominal subcutaneous adipose tissue between 30 and 300 min after a mixed meal in a small group of men and women (35). This positive balance was achieved by a combination of increasing uptake of triglycerides and reduced release of FFA. The results of the present study suggest that gender differences in the regional suppression of FFA release postprandially could contribute to differences in regional net lipid storage. Surprisingly, suppression of FFA release from leg adipose tissue in men was relatively greater than the suppression from other adipose tissue beds, although in absolute terms FFA release was comparable in men and women (Table III).

Mårin et al. (13, 14), have reported significant differences in regional adipose tissue uptake of meal triglycerides. After administering a meal with a labeled fatty acid, the relative uptake of meal fat can be measured by performing adipose tissue biopsies in different adipose tissue beds. Meal fatty acid storage was found to be slightly greater in abdominal adipose tissue than femoral adipose tissue in women (13). More recent studies have documented even greater uptake of meal triglycerides in the visceral adipose tissue of men (14). Although this experimental design addresses only one aspect of net meal triglyceride storage, if it were combined with measures of regional FFA release, this approach could provide a powerful means to examine the determinants of net triglyceride storage in different adipose tissue beds.

Meal fatty acids and plasma FFA. The use of a mixed meal experimental design is the only way to study the physiology of postprandial fatty acid storage and release. Because the liquid meal chosen for this study contained a disproportionate amount of triglyceride linoleate, there was a considerable change in the relative contribution of oleate (the traced fatty acid) to total FFA from the postabsorptive to the postprandial state. These differences were reflected in femoral and hepatic venous blood. 
It follows that an oleate tracer may not be ideal for study of FFA uptake after a meal, especially commercially available liquid meals. The change in the proportion of total FFA as oleate may result in changes in oleate uptake secondary competition with other FFA as they become a greater fraction of total FFA. This should not affect the use of oleate (or palmitate) as a tracer of FFA Ra.

In summary, lean, healthy men and women are significantly different in regard to the suppression of systemic lipolysis after a mixed meal and in the relative suppression of regional adipose tissue beds after meal consumption. Upper-body subcutaneous adipose tissue FFA release was found to be more resistant to postprandial antilipolytic events in men than in women, and this accounted for the lesser suppression of FFA flux in men after the meal. Upper-body adipose tissue is more lipolytically active than lower-body adipose tissue under basal conditions in both men and women, and postprandial events suppress FFA release from all adipose tissue beds. These results provide insight as to potential mechanisms for differences in regional fat distribution between men and women, and clarify some of the contradictory data available from in vitro studies.

\section{Acknowledgments}

We acknowledge the technical assistance of M. Leanne Barry, Rita Nelson, and Joan Aikens, as well the staff of the Mayo Clinic General Clinical Research Center and the Mayo Clinic Vascular Radiology Department, and Carol Demulling for editorial assistance.

This study was supported by the National Institutes of Health grants DK-45343 and RR-00585, and by the Mayo Foundation.

\section{References}

1. Boden, G., F. Jadali, J. White, Y. Liang, M. Mozzoli, X. Chen, E. Coleman, and C. Smith. 1991. Effects of fat on insulin-stimulated carbohydrate metabolism in normal men. J. Clin. Invest. 88:960-966.

2. Kelley, D. E., M. Mokan, J.-A. Simoneau, and L. J. Mandarino. 1993 Interaction between glucose and free fatty acid metabolism in human skeletal muscle. J. Clin. Invest. 92:91-98.

3. Saloranta, C., A. Franssila-Kallunki, A. Ekstrand, M.-R. Taskinen, and L. Groop. 1991. Modulation of hepatic glucose production by non-esterified fatty acids in Type 2 (non-insulin-dependent) diabetes mellitus. Diabetologia. 34:409415 .

4. Hennes, M. M. I., E. Shrago, and A. H. Kissebah. 1990. Receptor and postreceptor effects of free fatty acids (FFA) on hepatocyte insulin dynamics. Int. J. Obesity. 14:831-841.

5. Kissebah, A. H., S. Alfarsi, P. W. Adams, and V. Wynn. 1976. Role of insulin resistance in adipose tissue and liver in the pathogenesis of endogenous hypertriglyceridemia in man. Diabetologia. 12:563-571.

6. Jensen, M. D., M. W. Haymond, R. A. Rizza, P. E. Cryer, and J. M. Miles. 1989. Influence of body fat distribution on free fatty acid metabolism in obesity. J. Clin. Invest. 83:1168-1173.

7. Roust, L. R., and M. D. Jensen. 1993. Postprandial free fatty acid kinetics are abnormal in upper body obesity. Diabetes. 42:1567-1573.

8. Evans, D. J., R. G. Hoffmann, R. K. Kalkhoff, and A. H. Kissebah. 1984 Relationship of body fat topography to insulin sensitivity and metabolic profiles in premenopausal women. Metabolism. 33:68-75.

9. Martin, M. L., and M. D. Jensen. 1991. Effects of body fat distribution on regional lipolysis in obesity. J. Clin. Invest. 88:609-613.

10. Ross, R., K. D. Shaw, Y. Martel, J. de Guise, and L. Avruch. 1993. Adipose tissue distribution measured by magnetic resonance imaging in obese women. Am. J. Clin. Nutr. 57:470-475.

11. Kvist, H., B. Chowdhury, U. Grandgård, U. Tylén, and L. Sjöström. 1988. Total and visceral adipose-tissue volumes derived from measurements with computed tomography in adult men and women: predictive equations. Am. J. Clin. Nutr. 48:1351-1361.
12. Lemieux, S., D. Prud'homme, C. Bouchard, A. Tremblay, and J.-P. Deprés. 1993. Sex differences in the relation of visceral adipose tissue accumulation to total body fatness. Am. J. Clin. Nutr. 58:463-467.

13. Mårin, P., M. Rebuffé-Scrive, and P. Björntorp. 1990. Uptake of triglyceride fatty acids in adipose tissue in vivo in man. Eur. J. Clin. Invest. 20:158-165. 14. Mårin, P., B. Andersson, M. Ottosson, L. Olbe, Chowdhury B., H. Kvist, G. Holm, L. Sjöström, and P. Björntorp. 1992. The morphology and metabolism of intraabdominal adipose tissue in men. Metabolism. 41:1242-1248.

15. Jensen, M. D., P. J. Rogers, M. G. Ellman, and J. M. Miles. 1988. Choice of infusion-sampling mode for tracer studies of free fatty acid metabolism. Am. J. Physiol. (Endocrinol. Metab.) 254:E562-E565.

16. Miles, J. M., M. G. Ellman, K. L. McClean, and M. D. Jensen. 1987. Validation of a new method for the determination of free fatty acid turnover. Am. J. Physiol. (Endocrinol. Metab.) 252:E431-E438.

17. Pørksen, N., S. Munn, D. Ferguson, T. O'Brien, J. Veldhuis, and P. C. Butler. 1994. Coordinate pulsatile insulin secretion by chronic intraportally transplanted islets in the isolated perfused rat liver. J. Clin. Invest. 94:219-227.

18. Humprhreys, S. M., R. M. Fisher, and K. N. Frayn. 1990. Micro-method for measurement of sub-nanomole amounts of triacylglycerol. Ann. Clin. Biochem. 27:597-598.

19. Christie, W. W. 1985. Rapid separation and quantification of lipid classes by high performance liquid chromatography and mass (light-scattering) detection. J. Lipid Res. 26:507-512.

20. Jensen, M. D., J. A. Kanaley, L. R. Roust, P. C. O'Brien, J. S. Braun, W. L. Dunn, and H. W. Wahner. 1993. Assessment of body composition with use of dual-energy x-ray absorptiometry: evaluation and comparison with other methods. Mayo Clin. Proc. 68:867-873.

21. Jensen, M. D., V. Heiling, and J. M. Miles. 1990. Measurement of nonsteady-state free fatty acid turnover. Am. J. Physiol. (Endocrinol. Metab. 21) 258:E103-E108.

22. Havel, R. J., J. P. Kane, E. O. Balasse, N. Segel, and L. V. Basso. 1970. Splanchnic metabolism of free fatty acids and production of triglycerides of very low density lipoproteins in normotriglyceridemic and hypertriglyceridemic humans. J. Clin. Invest. 49:2017-2033.

23. Hagenfeldt, L., J. Wahren, B. Pernow, and L. Räf. 1972. Uptake of individual free fatty acids by skeletal muscle and liver in man. J. Clin. Invest. 51:2324-2330.

24. Groop, L. C., R. C. Bonadonna, D. C. Simonson, A. S. Petrides, M. Shank, and R. A. DeFronzo. 1992. Effect of insulin on oxidative and nonoxidative pathways of free fatty acid metabolism in human obesity. Am. J. Physiol. 263:E79-E84.

25. Nuutila, P., M. J. Knuuti, M. Mäki, H. Laine, U. Ruotsalainen, M. Teräs, M. Haaparanta, O. Solin, and H. Yki-Järvinen. 1995. Gender and insulin sensitivity in the heart and in skeletal muscles. Diabetes. 44:31-36.

26. McKeigue, P. M., A. Laws, Y. D. Chen, M. G. Marmot, and G. M. Reaven. 1993. Relation of plasma triglyceride and Apo B levels to insulin-mediated suppression of nonesterified fatty acids. Arteriosclerosis Thromb. 13:11871192.

27. Byrne, C. D., N. J. Wareham, D. C. Brown, P. M. S. Clark, L. J. Cox N. E. Day, C. R. Palmer, T. W. M. Wang, D. R. R. Williams, and C. N. Hales 1994. Hypertriglyceridaemia in subjects with normal and abnormal glucose tolerance: relative contributions of insulin secretion, insulin resistance and suppression of plasma non-esterified fatty acids. Diabetologia 37:889-896.

28. Wahrenberg, H., F. Lönnqvist, and P. Arner. 1989. Mechanisms underlying regional differences in lipolysis in human adipose tissue. J. Clin. Invest. 84:458467.

29. Smith, U., J. Hammersten, P. Björntorp, and J. G. Kral. 1979. Regiona differences and effect of weight reduction on human fat cell metabolism. Eur. $J$. Clin. Invest. 9:327-332.

30. Rebuffé-Scrive, M., P. Lönnroth, P. Mårin, C. Wesslau, P. Björntorp, and U. Smith. 1987. Regional adipose tissue metabolism in men and postmenopausal women. Int. J. Obes. 11:347-355.

31. Basso, L. V., and R. J. Havel. 1970. Hepatic metabolism of free fatty acids in normal and diabetic dogs. J. Clin. Invest. 49:537-547.

32. Pedersen, O., E. Hjøllund, and N. S. Sørensen. 1982. Insulin receptor binding and insulin action in human fat cells: effects of obesity and fasting. Metabolism. 31:884-895.

33. Arner, P., J. Bolinder, and J. Östman. 1983. Marked increase in insulin sensitivity of human fat cells 1 hour after glucose ingestion. J. Clin. Invest. 71:709-714.

34. Arner, P., J. Bolinder, P. Engfeldt, J. Hellmér, and J. Östman. 1984. Influence of obesity on the antilipolytic effect of insulin in isolated human fat cells obtained before and after glucose ingestion. J. Clin. Invest. 73:673-680.

35. Coppack, S. W., R. M. Fisher, G. F. Gibbons, S. M. Humphreys, M. J. McDonough, J. L. Potts, and K. N. Frayn. 1990. Postprandial substrate deposition in human forearm and adipose tissues in vivo. Clin. Sci. 79:339-348. 